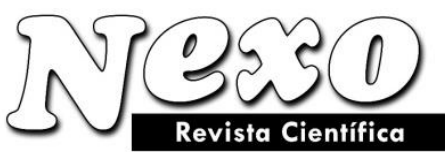

Vol. 34, No. 02, pp. 964-972/Junio 2021

\title{
Economic and legal aspects of the innovative activity of enterprises in the context of the digital economy
}

\section{Aspectos económicos y legales de la actividad innovadora de las empesas en el contexto de la economía digital}

\author{
Olga Vladimirovna Markova ${ }^{1, *}$, Ekaterina Yevgenievna Listopad ${ }^{2}$, Aleksandr Vladimirovich \\ Shelygov $^{3}$, Alexander Grigorievich Fedorov ${ }^{4}$, Igor Valentinovich Kiselevich ${ }^{5}$ \\ ${ }^{1}$ Moscow International University, Moscow, Russian Federation \\ ${ }^{2}$ Financial University under the Government of the Russian Federation, Moscow, Russian Federation \\ ${ }^{3}$ Moscow Polytechnic University, Moscow, Russian Federation \\ ${ }^{4}$ Kaluga State University named after K.E. Tsiolkovsky, Kaluga, Russian Federation \\ ${ }^{5}$ Russian University of Transport (MIIT), Moscow, Russian Federation \\ *markovaolga@yandex.ru
}

(recibido/received: 24-noviembre-2020; aceptado/accepted: 03-marzo-2021)

\begin{abstract}
The article deals with the economic and legal aspects of the innovative activity of enterprises in the context of the digital economy. The authors have established that the innovative activity of enterprises includes also the development of artificial intelligence and robotics and that in the current conditions when creating and using artificial intelligence technologies, the issue of ensuring national security in the digital environment becomes extremely important. In this case, the strategic goal of ensuring information security is to protect the vital interests of the individual and society against internal and external threats associated with the application of information technologies for various purposes contrary to civil law. It is proved that innovations will increase the investment attractiveness of the business, maintain a balance of creative freedom and internal control measures, self-regulation in the field of digital technologies, and develop a unified legal framework in the economic space.
\end{abstract}

Keywords: Investment attractiveness; Law; Information technology; Efficiency; Economy; Production.

\section{RESUMEN}

El artículo trata los aspectos económicos y legales de la actividad innovadora de las empresas en el contexto de la economía digital. Los autores han establecido que la actividad innovadora de las empresas incluye también el desarrollo de la inteligencia artificial y la robótica y que en las condiciones actuales a la hora de crear y utilizar tecnologías de inteligencia artificial, el tema de garantizar la seguridad nacional en el entorno digital se vuelve de suma importancia. En este caso, el objetivo estratégico de garantizar la seguridad de la información es proteger los intereses vitales del individuo y la sociedad contra las amenazas internas y externas asociadas con la aplicación de tecnologías de la información para diversos fines contrarios al derecho civil. Está comprobado que las innovaciones aumentarán el atractivo de 
inversión del negocio, mantendrán un equilibrio entre la libertad creativa y las medidas de control interno, la autorregulación en el campo de las tecnologías digitales y desarrollarán un marco legal unificado en el espacio económico.

Palabras claves: Atractivo de inversión; Ley; Tecnologías de la información; Eficiencia; Economía; Producción.

\section{INTRODUCTION}

The processes of socio-economic development are largely determined by the condition of digital electronic networks, which are the technical basis of the information revolution. The digital economy is one, and perhaps the most important result of this revolution. It is an economic activity in which the key factor of production is data in digital form, as well as processing large amounts of information and using the results of the analysis, which in comparison with traditional management can significantly improve the efficiency of various types of production, technologies, equipment, storage, sale, and delivery of goods and services. At the same time, a special place is given to the development of an innovative economy, which includes a system of production relations in the course of creating knowledge capital, fundamental scientific knowledge, innovation, and economic entities that generate added value through the creation and circulation of knowledge capital. However, based on the fact that the digital economy is currently booming, it requires an increasing amount of innovation and, consequently, fundamental scientific knowledge for their production. At the same time, any new type of economy that has been formed in the history of mankind, requires a large amount of the products of innovative economy, while not merging with the latter.

Besides, no technical innovations can become the basis for the formation of a new economy as a system of industrial relations, including the digital economy, without combining with organizational and managerial innovations that form the conceptual basis of any economy. Thus, technical and technological advances could not be effectively used until appropriate management innovations were developed and implemented. It is the sharp discrepancy between technical, organizational, and managerial capabilities that has caused a boom in the creation and dissemination of managerial innovations.

Issues of the innovative activity development of enterprises in the digital economy were considered in the works of L.V. Glukhova (2019), S.A. Korchagin (2018), S.N. Orlov (2018), M.P. Prokhorova (2020), M.V. Khachaturian (2018), S.S. Shuvalov (2019), et al. However, scientific publications do not fully uncover the economic and legal aspects of the innovative activities of enterprises in the digital economy.

\section{METHODS}

The theoretical and methodological basis of the research includes an abstract-logical method, methods of induction, deduction, analysis, synthesis, and systematization, used to substantiate approaches to the development of the innovative activity of enterprises in the digital economy, as well as graphic method, employed to study the level and trends of the enterprises' innovative activity parameters.

The information base of the article includes the data of state bodies, legislative and regulatory documents governing innovation activities, as well as the results of scientific research (Lobanov et al., 2020; Reznikova et al., 2020; Vinogradova et al., 2018).

In the course of the research, it is intended to justify the use of innovation as a basis for the digital economy, carry out analysis of the conditions contributing to the customization of the control system for the digital economy and the factors resisting this process, develop recommendations aimed at acceleration 
of innovation, which will serve the basis for the digital economy, as well as develop measures to coordinate the activities among the main participants of innovation.

\section{RESULTS}

In this case, it is necessary to consider the innovation infrastructure from the standpoint of the systembased description of the enterprise's performance and its corporate architecture. Therefore, one can use the approach of creating digital innovations, and intellectual property objects with a high level of knowledge intensity (Figure 1).

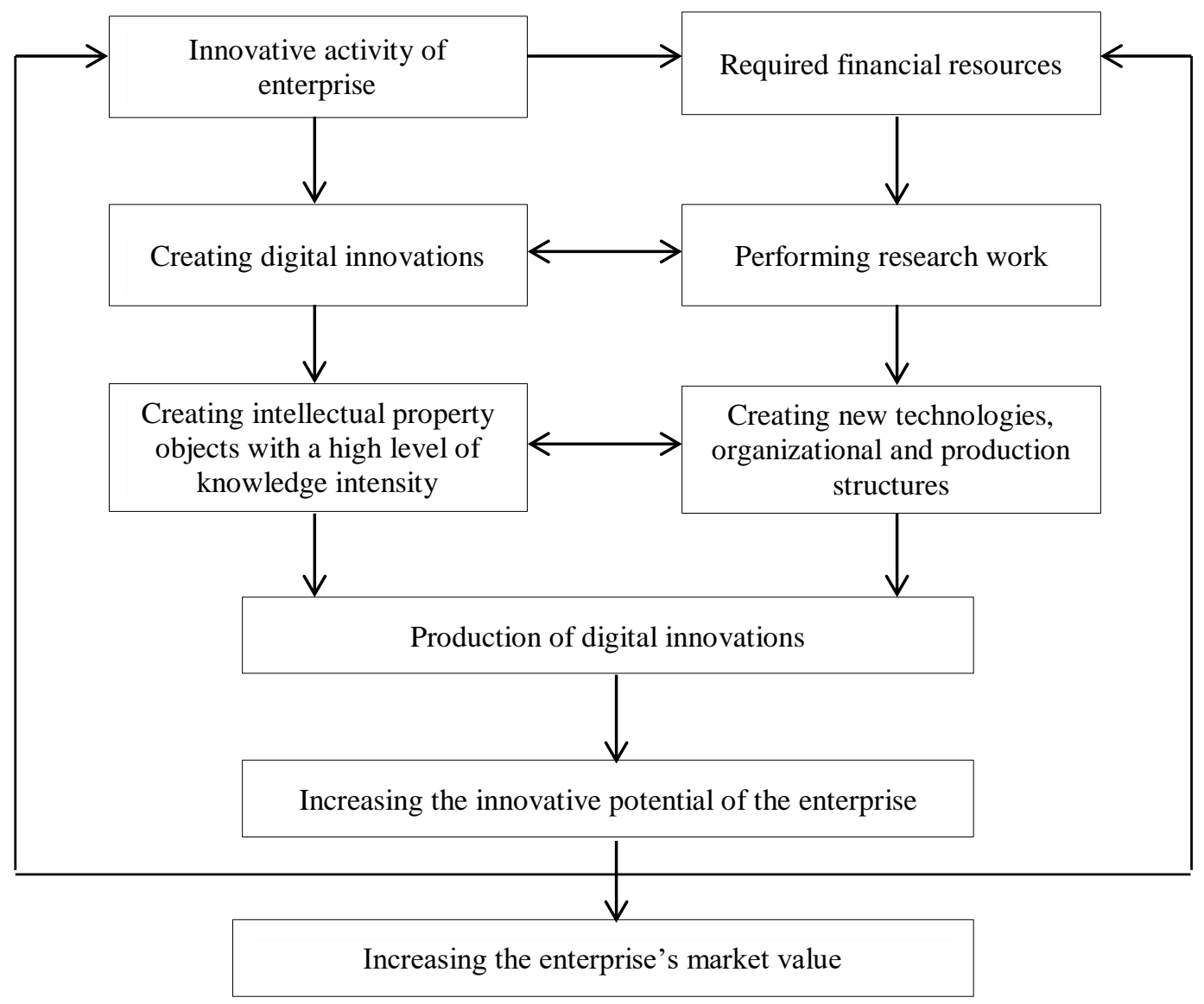

Figure 1. Innovative activity of the enterprise in the digital economy conditions

At the same time, the so-called business engineering includes the provision of services on a commercial basis for creating and operating infrastructure facilities in the contemporary economy, and the application of engineering methods to develop and operate solutions for organizing companies and nonprofit institutions. Besides, a process-oriented management approach, which allows the enterprise to restructure its activities in a rapidly changing environment, has acquired a key role in ensuring the efficiency of enterprise performance.

The prerequisites for the innovation development in the new environment include the transformation of the industrial economy into information- and knowledge-based economy, the emergence of a global economy, the transformation of the enterprise structure and management, and the emergence of fully automated enterprises. In this case, it is necessary to take into account the architecture of the digital 
enterprise, which is understood as a multidimensional process-oriented model integrated into the infrastructure of the enterprise's information system using cognitive technologies.

However, the emergence of digital management content in enterprises requires the involvement of the enterprise's knowledge management level. At the same time, the development of corporate knowledge management portals, analytical platforms of supporting and decision-making, the implementation of new intelligent information management technologies, allows improving activities and provides forecasting of results.

In this case, the new context of innovations is the possibility of their generation and dissemination through digital communications, the principles of organizing digital production, and the digital economy. However, the innovation revolution is characterized by the emergence of a high-speed broadband network, geographical expansion of broadband access networks, developments in the field of business applications based on modern corporate information systems, the emergence of virtual corporate structures, virtual enterprises, and the network economy.

The production, distribution, and use of knowledge as intangible assets of enterprises have great impact on management effectiveness. The emergence and implementation of new digital communication technologies have predetermined the transition of ordinary enterprises to digital ones, where content becomes the core of the organization, its digital asset, which allows working with it and using in all business processes.

At the same time, a digital enterprise is a system which uses new digital communication cognitive technologies at all levels of management - operational, strategic, and tactical, to improve its performance efficiency. As a decision-making tool, a digital enterprise uses the necessary information infrastructure that integrates digital content generated by key performance indicators of business processes. A digital enterprise is characterized by the fact that all-important business processes and management processes at all levels are implemented in electronic digital form.

The concept of innovative technologies involves consistent, continuous change and improvement of business processes in product development, design, production, and operation, using a variety of methods. In this case, information support for innovations is implemented as a life cycle of the enterprise's information system when organizing parallel engineering of resources to arrange efficient production. Thus, any product, such as an algorithm, mechanism, technique, software product, or information system can be understood as a subject of intellectual work.

However, an enterprise information system can be either an end product or a tool involved in the production of any other product. Similarly, considering innovation as a new product or service, all the definitions in describing the life cycle are applied to it. Moreover, considering the life cycle managing process of technological innovation as a business process in the concept, the latter can also be considered as a product that has a cost and a price.

Typical stages of the product life cycle include marketing and market exploration, product design and development, process planning and development, procurement, manufacturing or service provision, inspections, installation and commissioning, after-sales activities, technical assistance in maintenance, sales, and distribution, as well as end-of-life disposal or recycling. Essentially, these stages are no different from the stages of innovation management in the course of innovation design and implementation.

At that, the projecting of any business process that provides the product life cycle can be carried out in three main stages: 
- collecting a priori economic information about the application domain of production, which consists in analyzing the current situation, developing a set of functional models of business processes that describe the current state of the environment in which the life cycle of innovations is implemented, developing and comparing possible alternatives to improve both individual processes and the system in general;

- monitoring the innovation life cycle processes, whose results are as follows: functional models of business processes of the innovation life cycle; functional models of alternative options for improved business processes; cost and risk assessment for each option; selection of the preferred option; description of the technical architecture and evaluation of the technical characteristics of the information system for the selected option; assessment and forecast of essential parameters of the integrated business process according to the balanced innovation life cycle assessment chart, such as customer expectations, assessment of fixed assets, and the degree of staff training;

- destructing outdated production or improving the existing one.

In this case, organizational and managerial innovations are of particular importance, since they are aimed at gradual improving or achieving significant and rapid changes in the organizational structure and management of the enterprise through the implementation of individual innovative systems, technologies, methods, tools, ways of organizing and managing production, as well as technological, financial and economic, social and human resources, logistics and info-communication subsystems or a set of new technologies, methods, tools, and ways of organization.

Organizational and managerial innovations should be aimed at improving the efficiency of individual parts of the management system, management of particular activities and the entire management system of the enterprise in general by creating conditions through the implementation of organizational and managerial innovations to ensure the ability to meet current requirements of the internal and external environment, as well as to achieve structural and functional advantages.

This opens up opportunities for improving the efficiency of innovation, economic and general security of the enterprise, the use of knowledge, the efficiency of labor processes and workplace organization, as well as reducing transaction costs, improving the quality of products, results of performance, development, and competitiveness of the entire enterprise.

In a narrower sense, organizational and managerial innovations are related to the processes of optimal organization of production, transport, sales, and supply. However, organizational mechanisms focused on innovation, which provide higher flexibility of the enterprise, are necessary because the functions of managing innovation development are dispersed in the managerial apparatus over different divisions. However, managerial innovations include new methods, technologies, and organization of management processes, project and quality management systems.

But the process of forming any economy is based on an effective combination of technical and technological, as well as organizational and managerial innovations, whose main function is to ensure the continuous growth of the flow of innovations in production, primarily technical and technological ones, as well as their implementation. At the same time, the industrial economy has also developed based on a combination of advanced technologies of its time with management theory, which includes modern management as an important part of management science. Based on the above, organizational and managerial innovations currently exist and continue to be created. They can be considered a conceptual platform for the digital economy. 
However, structural global changes are associated with an increased role of high-tech sectors in the formation of gross domestic product, integration, and globalization of industrial production, and the transition to a digital economy, which leads to a change in the organizational and economic paradigm of competitiveness. The gradual transition to the organization of innovative development in the industry based on global research networks, in particular in the form of elements of network-type innovation infrastructure, such as virtual network innovation alliances, strategic technology platforms, and innovation clusters may serve an example of this process.

At that, the new stage of the digital revolution is characterized by the convergence of technologies, blurring the lines between physical, digital, and biological spheres, the emergence of additive manufacturing, new means of communication, cloud computing, and cybersecurity. Therefore, corporate culture, as part of the organizational and managerial resources of the enterprise, has always served the most important strategic resource for its development. When switching to modern digital technologies, the corporate culture will have to be transformed, accumulating the most important innovations that the market requires.

At the same time, the prevailing technological mode is currently at the stage of maturity and characterized primarily by the predominance of digital communications in the production and life of the human community, which has created conditions for the formation of a digital economy and information society in general on their basis. Besides, the technological mode is being formed which implies a radical change in the dominant production technologies, which will likely emerge from the new generation of cognitive technologies.

Currently, the Russian society came up to a common opinion that the development of innovative activities is one of the necessary conditions for transiting to a new information stage of economic development and a mandatory attribute of market relations. One can say that innovative resources for the modern economy are the main development vector of countries and can become a profitable alternative to raw materials.

The practice has shown that information, knowledge, and human capital, unlike raw materials, are inexhaustible resources. In this case, digital rights are implemented whose content and conditions are determined according to the rules of the information system that meets the criteria established by law. Thus, this refers to a set of electronic data certifying rights to objects of civil rights, such as things, other property, deliverables, services, and exclusive rights. However, the legislative framework for regulating innovation activity in Russia lags far behind the pace of the development of very innovative activities (Figure 2).

The current law regulating scientific and technical, as well as partly innovative activities, is the Federal Law of the Russian Federation "On science and state scientific and technical policy", which predominantly is declarative and even restrictive. It lacks provisions defining the innovation activity objects, which are not always protectable subjects of intellectual property.

However, in the light of the existing draft legislation, a newly emerging subject of legal regulation is being conceptualized, as well as public relations with the involvement of subjects of scientific and related research, expert and educational activities, identifying the specifics of methods of influencing them and the conditions for effective investment in the context of the developing digitalization of society. 


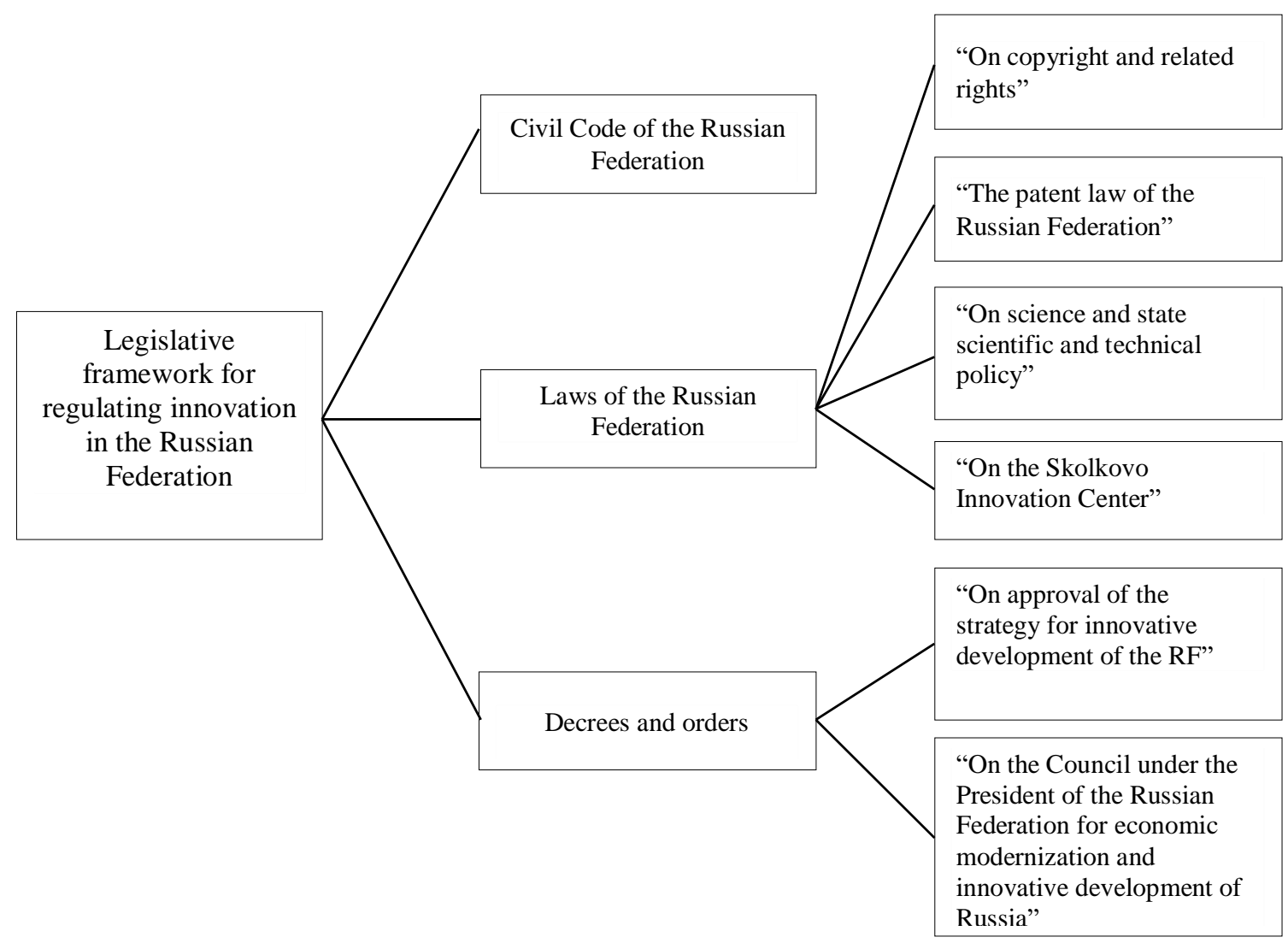

Figure 2. Legal regulation of innovative activities in the Russian Federation

\section{DISCUSSION}

The reliability of the presented approaches is confirmed by the fact that the attitude of the Russian Federation in the world ranking of internal $R \& D$ expenditures remains almost unchanged. At that, about two-thirds of these expenditures are funded from the state budget, and only one-third is funded from the business sector (Latysheva et al., 2019; Nikolskaya et al. 2018; Voskovskaya et al., 2020). In this case, it is necessary to create all possible legislative prerequisites for a significant increase in the proportion of business in research and development expenditures. In technology-leading countries, which Russia should join, the proportion of research and development spending is completely different.

It can be argued that to build a national innovation system in the Russian Federation, in which researchers, businesses, and the state would successfully interact to create a favorable legal environment to implement strategic tasks in the field of technology development, it is necessary to adopt a substantially new law on innovation activities in the Russian Federation. The new law should not only address existing issues of legal regulation of innovation but also set a development and implementation vector of new technologies and objects of innovation into circulation. At that, the new law should not restrict the freedom of creativity and impose increased control functions on the state.

However, an approach based on self-regulation in the field of digital technologies can be considered as well. In its traditional sense, self-regulation can be used very effectively for the digital technology industry around the world since today there is actually no effective legal regulation of the use of modern digital technologies. Self-regulation of the innovation sector can help businesses to integrate developments into an economic turnover. 
Concepts, such as artificial intelligence and robotics result from human intellectual activity, rather than from fiction. Nevertheless, several extremely sensitive alternatives in this direction have not yet been passed and are the subject of discussions by experts around the world. The accessibility of big data for developers, or additional control and security measures to protect personal data and private life of citizens; simplified certification and fastest way to market, or conservatism associated with the higher complexity of such systems; the distribution of benefits and responsibilities among users, developers, and information providers; the digital identity of a person and the risks of counterfeiting; and finally, creating new jobs or losing them with the advent of smart machines are the issues which require competent and accurate decisions.

In Russia, the development of artificial intelligence is also a priority direction. This was confirmed by the approval of the National Strategy for the Development of Artificial Intelligence (NSDAI), which defines the goals and main objectives of the artificial intelligence development that is understood as a set of technological solutions allowing simulating human cognitive functions and obtaining results comparable to the results of human intellectual activity when performing specific tasks.

The practice has shown that one of the cooperation areas in the field of artificial intelligence is to ensure appropriate legal and ethical standards that are based on basic rights and values, including privacy and personal data protection, as well as principles, such as transparency and accountability, working to improve information security, ensuring security and vigilance in the course of development and application of artificial intelligence technologies.

\section{CONCLUSION}

Summing up, it can be concluded that the innovative activities of enterprises include the development of artificial intelligence and robotics. In the current conditions, the issue of ensuring national security in the digital environment when creating and using artificial intelligence technologies becomes extremely important. In this case, the strategic goal of ensuring information security is to protect the vital interests of the individual and society against internal and external threats associated with the use of information technologies for various purposes contrary to civil law.

Therefore, taking into account the experience of enterprises, to achieve a high level of innovations turnover, investment attractiveness, while respecting safety, including that in the digital environment, innovative legislation should be comprehensive, therefore, the following areas should be developed: ensuring investment attractiveness for business; complying with the ethics, security, and interests of the society in the technological race; maintaining a balance between creative freedom and internal control measures; ensuring self-regulation in the field of digital technologies and innovation; and developing a unified legal framework in the economic space.

\section{REFERENCES}

Glukhova, L. V. and Nemtsev, A. D. (2019). Upravlenie riskami realizacii programmy "Cifrovaya ekonomika Rossijskoj Federacii" [Risk management when implementing the program on Digital Economy of the Russian Federation]. Bulletin of the Volzhsky University named after V.N. Tatishchev, 2 (1), 70-78.

Khachaturian, M. V. (2018). Osobennosti razvitiya sistem upravleniya vladel'cheskimi riskami v usloviyah formirovaniya "cifrovoj" ekonomiki [Features of development of possessory risks 
management systems in the context of the digital economy formation]. Economy and Entrepreneurship, 1 (90), 874-876.

Korchagin, S. and Polshikov, B. (2018). Cifrovaya ekonomika i transformaciya mekhanizmov gosudarstvennogo upravleniya: riski i perspektivy dlya Rossii [Digital economy and transformation of public administration mechanisms: Risks and prospects for Russia]. Free Thought, 1 (1667), 23-36.

Latysheva, Z. I., Skripkina, E. V., Mamrukova, O. I., Listopad, E. Y. and Zholudeva, V. V. (2019). Technology and organization of accounting: recent changes. International Journal of Recent Technology and Engineering, 8 (4), 12737-12740.

Lobanov, I. V., Mudrova, S. V., Potekhina, E. V., Shelygov, A. V. and Pominova, A. I. (2020). Formation of an education digitalization strategy in present-day conditions. Propositos y Representaciones, 8 (S3), e777.

Nikolskaya, E. Yu., Kovaleva, N. I., Uspenskaya, M. E., Makshakova, N. I., Lysoivanenko, E. N. and Lebedev, K. A. (2018). Innovative quality improvements in hotel services. European Research Studies Journal, 21 (2), 489-498.

Orlov, S. N. and Tatarintsev, A. V. (2018). Osobennosti upravleniya kreditnymi riskami v usloviyah cifrovoj ekonomiki [Features of credit risk management in the digital economy]. Innovative development of the economy: Trends and prospects, 1, 240-245.

Prokhorova, M. P., Bulganina, S. V., Belousova, K. V. and Labazova, A. V. (2020). Upravlenie chelovecheskimi resursami i riski cifrovoj ekonomiki [Human resource management and risks of digital economy]. Science of Krasnoyarye, 9 (4-2), 111-116.

Reznikova, O. S., Ganieva, A. K., Verna, V. V., Korolenko, J. N. and Shelygov, A. V. (2020). Determinants of the Russian labor market model. Revista Inclusiones, 7 (Especial), 260-267.

Shuvalov, S. S. (2019). Klyuchevye riski razvitiya cifrovoj ekonomiki: novye vyzovy dlya sistemy gosudarstvennogo upravleniya [Key risks of digital economy development: New challenges for the public administration system]. Management and Business Administration, 2, 417.

Vinogradova, E. V., Mukhlynina, M. M., Mukhlynin, D. N., Solovyeva, N. V. and Lebedeva, O. Ye. (2018). Economic and legal aspects of environmental safety. Journal of Environmental Management and Tourism, 9 (1(25)), 144-150.

Voskovskaya, A. S., Karpova, T. A., Rostovtseva, P. P., Guseva, N. V. and Shelygov, A. V. (2020). Development of the learning process management in the context of digitization. Revista Inclusiones, 7 (S4-5), 240-249. 